\title{
The speciation of cobalt in seawater and fresh waters at $25^{\circ} \mathrm{C}$
}

\author{
Pujing PAN ${ }^{1}$ and Nicholas J. SuSAK ${ }^{2}$ \\ Laboratory for Experimental Geochemistry and Modelling, Department of Geological Sciences, \\ McGill University, 3450 University Street, Montreal, Quebec ${ }^{1}$, Canada H3A 2A7, \\ and Department of Geology, University of New Brunswick, Fredericton, N.B. ${ }^{2}$ Canada E3B 5A3
}

(Received August 8, 1991; Accepted December 2, 1991)

\begin{abstract}
Cobalt(II) speciation in seawater and fresh waters was calculated using recent spectrophotometrically determined stability data for cobalt(II) chloride and bromide complexes in aqueous solutions, and a theoretically estimated stability constant for the cobalt(II) bicarbonate complex. Calculations for seawater suggest that $56.25 \%$ of total dissolved cobalt(II) occurs as the free ion, $\mathrm{Co}^{2+}, 39.53 \%$ as $\mathrm{CoCl}^{+}, 2.76 \%$ as $\mathrm{CoCl}_{2}^{0}, 1.02 \%$ as $\mathrm{CoSO}_{4}^{0}$, and less than $1.0 \%$ as $\mathrm{CoNH}_{3}^{2+}, \mathrm{CoCO}_{3}^{0}, \mathrm{CoHCO}_{3}^{+}, \mathrm{CoCl}_{3}^{-}$, $\mathrm{CoF}^{+}$and $\mathrm{CoBr}^{+}$. In neutral to acidic fresh waters, $90 \%$ or more of the dissolved cobalt(II) occurs as the free ion. $\mathrm{CoCO}_{3}^{0}$ becomes important in basic fresh waters $(\mathrm{pH}>8.5)$, and predominant in very basic fresh waters $(\mathrm{pH}>9.5)$. Co(II) organic complexes are not included in the calculations, discussions suggest that they are unlikely to be abundant in seawater. Co(II) organic complexes may, however, be important in fresh waters, and future work should investigate this possibility.
\end{abstract}

\section{INTRODUCTION}

The speciation of a metal in natural waters is of primary significance, because it is the species of a metal which determine its chemical activity and toxicity. Although the concentration of cobalt in natural waters is very low (in seawater, about $1 \times 10^{-10} \mathrm{~m}$, Ahrland, 1985; $6.87 \times 10^{-9}$ $m$, Goldberg, 1980), as the principal constituent of Vitamin $\mathrm{B}_{12}$ and methymalonyl GA mutase in livers, cobalt is one of the essential trace elements for man and animals (Brooks, 1977). It is therefore important to understand the behavior of cobalt in the environment, especially in natural waters. Unfortunately, controversy exists over cobalt speciation in seawater. Horne (1965) suggests that the free ion, $\mathrm{Co}^{2+}$ and $\mathrm{CoSO}_{4}^{0}$ are the principal dissolved species of cobalt in seawater. The model of Turner et al. (1981) suggests that $88 \%$ of cobalt in seawater is present as $\mathrm{Co}^{2+}$ and $\mathrm{CoCl}^{+}$(see Table 1). Stumm and Brauner (1975) and Stumm and Morgan (1981) state that the principal cobalt species in seawater are the free ion, $\mathrm{Co}^{2+}$, and possibly,
$\mathrm{CoCO}_{3}^{0}$. Ahrland (1985) and Byrne et al. (1988) made similar, but more complete inference for cobalt speciation in seawater (Table 1). Most of the above authors indicate that $\mathrm{Co}$ (II) is a fairly "hard" acceptor in the Pearson (1963) sense. Complexes of cobalt(II) with oxy-anions will be much more stable than with halides (excluding $\mathbf{F}^{-}$). Because sufficiently reliable stability constants were not available at the time of these early studies, calculations of cobalt speciation in seawater were based mainly on theoretical estimation. Because stability constants for Co(II) bicarbonate complexes are still not available, all the above speciation schemes of $\mathrm{Co}$ (II) in seawater do not take the bicarbonate complexes into account.

Millero's (1974) review of trace elements such as $\mathrm{Cu}, \mathrm{Zn}, \mathrm{Cd}, \mathrm{Hg}$ and $\mathrm{Pb}$, which have been studied in more detail, indicates a few general points of agreement among authors: 1) only a small portion of trace metals exists in seawater as the free ion; 2) with few exceptions, chloride complexes are the dominant complexed species; 3) $\mathrm{F}^{-}, \mathrm{Br}^{-}$and $\mathrm{SO}_{4}^{2-}$ are not important complex- 
Table 1. Calculated cobalt species distribution in seawater

\begin{tabular}{|c|c|c|c|c|c|}
\hline \multirow{2}{*}{ Species } & \multirow{2}{*}{$\stackrel{m}{m}$ (This work) } & \multicolumn{4}{|c|}{$\%$} \\
\hline & & This work & (1) & (2) & (3) \\
\hline $\mathrm{Co}^{2+}$ & $3.87 \times 10^{-9}$ & 56.25 & 42. & 58. & 65. \\
\hline $\mathrm{CoCl}^{+}$ & $2.72 \times 10^{-9}$ & 39.53 & 24. & 30. & 14. \\
\hline $\mathrm{CoCl}_{2}^{0}$ & $1.9 \times 10^{-10}$ & 2.76 & & & \\
\hline $\mathrm{CoCl}_{3}^{-}$ & $2.0 \times 10^{-12}$ & 0.03 & & & \\
\hline $\mathrm{CoCl}_{4}^{2-}$ & $3 . \times 10^{-15}$ & $<0.01$ & & & \\
\hline $\mathrm{CoBr}^{+}$ & $9.7 \times 10^{-13}$ & 0.01 & & & \\
\hline $\mathrm{CoBr}_{2}^{0}$ & 3. $\times 10^{-17}$ & $<0.01$ & & & \\
\hline $\mathrm{CoBr}_{3}^{-}$ & 2. $\times 10^{-22}$ & $<0.01$ & & & \\
\hline $\mathrm{CoBr}_{4}^{2-}$ & $2 . \times 10^{-28}$ & $<0.01$ & & & \\
\hline $\mathrm{CoNH}_{3}^{2+}$ & $1.25 \times 10^{-11}$ & 0.18 & & & \\
\hline $\mathrm{Co}\left(\mathrm{NH}_{3}\right)_{2}^{2+}$ & 1. $\times 10^{-14}$ & $<0.01$ & & & \\
\hline $\mathrm{Co}\left(\mathrm{NH}_{3}\right)_{3}^{2+}$ & 3. $\times 10^{-18}$ & $<0.01$ & & & \\
\hline $\mathrm{Co}\left(\mathrm{NH}_{3}\right)_{4}^{2+}$ & $4 \times 10^{-22}$ & $<0.01$ & & & \\
\hline $\mathrm{CoF}^{-}$ & $5.4 \times 10^{-13}$ & 0.01 & & & \\
\hline $\mathrm{CoOH}^{+}$ & $8 . \times 10^{-25}$ & $<0.01$ & 0.4 & 1. & 1. \\
\hline $\mathrm{CoSO}_{4}^{\circ}$ & $7.0 \times 10^{-11}$ & 1.02 & 5. & 5. & 5. \\
\hline $\mathrm{CoCO}_{3}^{0}$ & $7.2 \times 10^{-12}$ & 0.10 & 28. & 6. & 14. \\
\hline $\mathrm{CoHCO}_{3}^{+}$ & $5.5 \times 10^{-12}$ & 0.08 & & & \\
\hline $\mathrm{CoH}_{2} \mathrm{PO}_{4}^{+}$ & $3 . \times 10^{-13}$ & $<0.01$ & & & \\
\hline $\mathrm{Co}\left(\mathrm{IO}_{3}\right)_{2}^{0}$ & 2. $\times 10^{-21}$ & $<0.01$ & & & \\
\hline $\mathrm{CoH}_{2} \mathrm{~S}$ & $<1 \times 10^{-99}$ & $<0.01$ & & & \\
\hline Total & $6.87 \times 10^{-9}$ & 99.97 & 99.4 & 100. & 99 \\
\hline
\end{tabular}

References: (1) Ahrland (1985); (2) Turner et al. (1981); (3) Byrne et al. (1988).

ing ligands; and 4) $\mathrm{CO}_{3}^{2-}$ may be an important complexing ligand only for $\mathrm{Pb}$. A recent study by Byrne et al. (1988) confirmed these observations, with the exception of $\mathrm{Zn}$, which was calculated to occur mostly as the free ion in seawater. Because $\mathrm{Cu}, \mathrm{Zn}, \mathrm{Cd}, \mathrm{Hg}$ and $\mathrm{Pb}$ are also fairly "hard", the above observations cast doubt upon the previously proposed cobalt speciation schemes in seawater (Table 1). A recent contribution on Co(II) halide complexes by Pan and Susak (1989) have made it necessary and possible to reexamine $\mathrm{Co}(\mathrm{II})$ speciation in seawater.

\section{Modelling}

Figure 1 is an Eh-pH diagram for the Co$\mathrm{H}_{2} \mathrm{O}$ system. Since $\mathrm{Co}^{3+}$ is stable only at very oxidized conditions, which is unlikely in natural waters, attention will be focused on $\mathrm{Co}^{2+}$.

Because seawater has a near-constant composition throughout the world oceans, and a

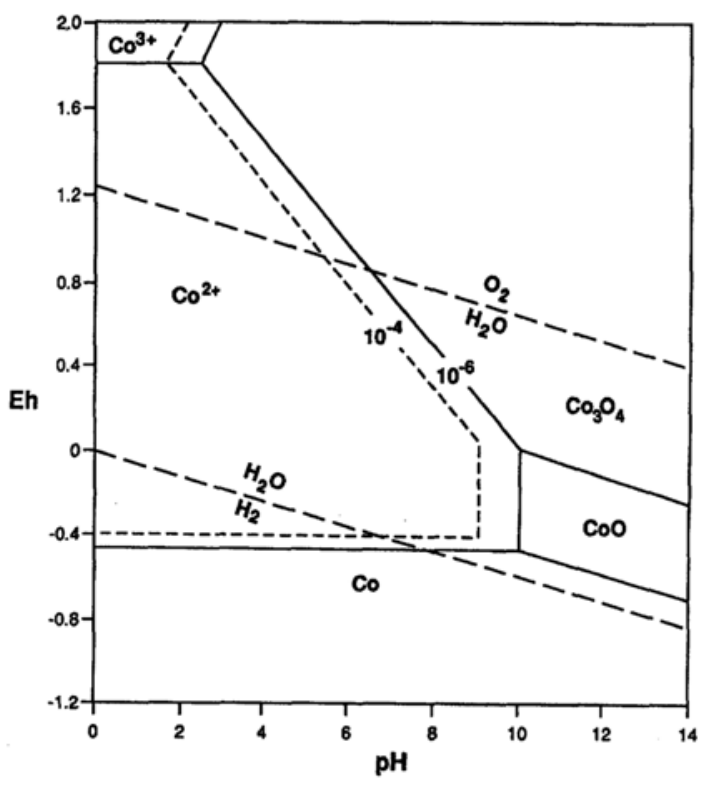

Fig. 1. Eh-pH diagram for the $\mathrm{Co}-\mathrm{H}_{2} \mathrm{O}$ system at $25^{\circ} \mathrm{C}$. Data from Karapet'yants and Karapet'yants (1970). 
large portion of the thermodynamic data at $25^{\circ} \mathrm{C}$ in the literature were determined in solutions of a constant ionic strength of seawater, it is convenient to define our standard state solution to be at $298.15 \mathrm{~K}$ and $1 \mathrm{bar}$, and with an ionic strength of seawater (0.714). By definition,

$$
\beta=\frac{\Pi a_{i}^{v_{i}}}{\Pi a_{j}^{v_{j}}}=\frac{\Pi m_{i}^{v_{i}}}{\Pi m_{j}^{v_{j}}} \cdot \frac{\Pi \gamma_{i}^{v_{i}}}{\Pi \gamma_{j}^{v_{i}}}
$$

where $\beta$ is the stability constant with the conventional standard state; $a$ is the chemical activity of reactant species, $j$, or product species, $i$; $v$ is the stoichiometric coefficient; $m$ is the molality; $\gamma$ is the activity coefficient. The stability constant with our defined standard state, $\beta^{\prime}$ is given by

$$
\beta^{\prime}=\frac{\Pi m_{i}^{v_{i}}}{\Pi m_{j}^{v_{j}}}=\beta \frac{\Pi \gamma_{j}^{v_{i}}}{\Pi \gamma_{i}^{v_{i}}}
$$

With the standard state defined above, the concentration of water can be taken as unity, and the molality of a species equals its activity. For simplicity, all bound waters will be dropped from the formulas of the complexes. Based on previous studies (Millero, 1974; Turner et al., 1981; Ahrland, 1985; Byrne et al., 1988), it is expected that the dominant cobalt(II) species in seawater are the free ion, and the chloride, carbonate and sulfate complexes. In our model, in addition to the free ion, $\mathrm{Co}^{2+}$, we consider the following 20 complexes:

$\begin{array}{lllll}\mathrm{CoCl}^{+} & \mathrm{CoCl}_{2}^{0} & \mathrm{CoCl}_{3}^{-} & \mathrm{CoCl}_{4}^{2-} & \mathrm{CoBr}^{+} \\ \mathrm{CoBr}_{2}^{0} & \mathrm{CoBr}_{3}^{-} & \mathrm{CoBr}_{4}^{2-} & \mathrm{CoOH}^{+} & \mathrm{CoSO}_{4}^{0} \\ \mathrm{CoCO}_{3}^{0} & \mathrm{CoHCO}_{3}^{+} & \mathrm{CoF}^{+} & \mathrm{CoH}_{2} \mathrm{~S}^{2+} & \mathrm{CoH}_{2} \mathrm{PO}_{4}^{+} \\ \mathrm{Co}\left(\mathrm{IO}_{3}\right)_{2}^{0} & \mathrm{CoNH}_{3}^{2+} & \mathrm{Co}\left(\mathrm{NH}_{3}\right)_{2}^{2+} & \mathrm{Co}\left(\mathrm{NH}_{3}\right)_{3}^{2+} & \mathrm{Co}\left(\mathrm{NH}_{3}\right)_{4}^{2+} .\end{array}$

We cannot include all possible Co(II) species in seawater in the list, due to the lack of appropriate thermodynamic data. However, the Co(II) hydroxide, sulfate and fluoride complexes are adequately represented by their first step complexes, as the first step complexes are usually the strongest. When ligand concentrations are very low, as in the present calculations, the concentrations of the first step complexes are usually much higher than those of complexes with higher coordination numbers (Appendix I). The $\mathrm{Co}$ (II) phosphate, iodate and bisulfide complexes are represented by $\mathrm{CoH}_{2} \mathrm{PO}_{4}^{+}$, $\mathrm{Co}\left(\mathrm{IO}_{3}\right)_{2}^{0}$ and $\mathrm{CoH}_{2} \mathrm{~S}^{2+}$ respectively (data for only these complexes are available), which may not be the most abundant $\mathrm{Co}$ (II) bisulfide, phosphate and iodate complexes, but should be close enough to evaluate such terms. When the total concentrations of these complexes are very low (as demonstrated below), it is probably sufficient to know their relative orders of magnitude for the purpose of comparison.

For the $i$ th complex,

$$
\left[C_{i}\right]=\beta_{i}^{\prime}\left[\mathrm{Co}^{2+}\right]\left[L_{i}\right]^{v_{i}}
$$

where $C_{i}$ and $\beta_{i}^{\prime}(i=1 \cdots 20)$ are the ith cobalt(II) complex and its stability constant, respectively, and $L_{i}$ and $v_{i}$ are the ith ligand and its stoichiometric coefficient. Note that the concentrations of both cobalt and the ligand in equation (3) are those of the free ions (equilibrium concentrations), not the total ones. Taking total cobalt concentration in seawater to be $6.87 \times 10^{-9} \mathrm{~m}$ (Goldberg, 1980), then

$$
\begin{aligned}
& {\left[\mathrm{Co}^{2+}\right]+\left[\mathrm{CoF}^{-}\right]+\sum_{n=1}^{4}\left[\mathrm{CoCl}_{n}^{2-n}\right]+\sum_{n=1}^{4}\left[\mathrm{CoBr}_{n}^{2-n}\right]+\sum_{n=1}^{4}\left[\mathrm{Co}\left(\mathrm{NH}_{3}\right)_{n}^{2+}\right]+\left[\mathrm{CoOH}^{+}\right]} \\
& +\left[\mathrm{CoH}_{2} \mathrm{~S}^{2+}\right]+\left[\mathrm{Co}\left(\mathrm{IO}_{3}\right)_{2}^{0}\right]+\left[\mathrm{CoSO}_{4}^{0}\right]+\left[\mathrm{CoCO}_{3}^{0}\right]+\left[\mathrm{CoHCO}_{3}^{+}\right] \\
& +\left[\mathrm{CoH}_{2} \mathrm{PO}_{4}^{-}\right]=6.87 \times 10^{-9}
\end{aligned}
$$


By substituting equation (3) into equation (4), the latter equation can be solved when all the necessary $\beta$ 's and free ligand concentrations, $\left[L_{i}\right]$, are known.

\section{Stability Constants and Free Ligand Concentrations}

The discrepancies in cobalt speciation schemes for seawater are primarily a result of the different stability constants of cobalt(II) complexes (or ion-pairs) used by different authors. The stability constants of cobalt(II) chloride complexes in the literature are highly variable (discussed in Pan, 1989; Pan and Susak, 1989). Therefore, a demonstrably valid set of data is required to calculate $\mathrm{Co}$ (II) speciation in seawater. Besides, in seawater $(\mathrm{pH}=8.2)$, more than $99 \%$ of total dissolved carbon occurs as bicarbonate ion in solution. Thus, the cobalt(II) bicarbonate complex has to be considered in order to calculate a complete speciation scheme for $\mathrm{Co}(\mathrm{II})$ in seawater.

In a spectrophotometric study of Co(II)chloride and -bromide complexes, Pan and Susak (1989) obtained the stability constants of all complexes using a combination of graphical and numerical methods. With the distinction between octahedral (6-fold) and tetrahedral (4fold) complexes and the correction to activities, we believe that the stability constants reported in Pan and Susak (1989) are better estimates than previously reported ones. All $\beta$ 's for octahedral chloro- and bromo-cobalt (II) complexes at $25^{\circ} \mathrm{C}$ and $\mathrm{I}=0.714$ (formal ionic strength of seawater, Ahrland, 1985) were calculated using the data of Pan and Susak (1989), and listed in Table 2.

No stability data for Co (II) bicarbonate complexes are available in the literature. Nevertheless, numerous studies (Hancock et al., 1977; Chen et al., 1984; Elliott, 1988; Mountain and Wood, 1988) suggest that linear free energy relations hold for many metals and ligands. Figure 2 shows such a linear free energy relationship, i.e. $\log \beta^{\prime}\left(\mathrm{MHCO}_{3}^{+}\right)$against $\log \beta^{\prime}\left(\mathrm{MCO}_{3}^{0}\right)$, for $\mathrm{Fe}^{2+}, \mathrm{Cu}^{2+}, \mathrm{Ca}^{2+}$ and $\mathrm{Mg}^{2+}$. A regression line was obtained with a correlation coefficient 0.97 . From this regression equation, we calculated that $\log \beta^{\prime}$ for equation (5) below is 0.819 , given that $\log \beta^{\prime}$ for equation (6) is 3.01 (Byrne et al., 1988).

$$
\begin{aligned}
& \mathrm{Co}^{2+}+\mathrm{HCO}_{3}^{-}=\mathrm{CoHCO}_{3}^{+} \\
& \mathrm{Co}^{2+}+\mathrm{CO}_{3}^{2-}=\mathrm{CoCO}_{3}^{0}
\end{aligned}
$$

The apparent stability constant of the Cobalt(II) sulfate complex in Table 2 was calculated from the value at infinite dilution (Izatt et al., 1969). The data of Izatt et al. (1969) was used, because it was determined using a

Table 2. Data used in cobalt speciation calculations in seawater

\begin{tabular}{llcccc}
\hline & $-\log (m)$ & $\log \beta_{1}^{\prime}$ & $\log \beta_{2}^{\prime}$ & $\log \beta_{3}^{\prime}$ & $\log \beta_{4}^{\prime}$ \\
\hline $\mathrm{Cl}^{-}$ & $0.253^{\mathrm{a}}$ & $0.100^{\mathrm{b}}$ & $-0.816^{\mathrm{b}}$ & $-2.54^{\mathrm{b}}$ & $-5.11^{\mathrm{b}}$ \\
$\mathrm{Br}^{-}$ & $3.07^{\mathrm{a}}$ & $-0.538^{\mathrm{b}}$ & $-2.00^{\mathrm{b}}$ & $-4.10^{\mathrm{b}}$ & $-7.02^{\mathrm{b}}$ \\
$\mathrm{OH}^{-}$ & $5.8^{\mathrm{c}}$ & $-9.9^{\mathrm{c}}$ & & & \\
$\mathrm{F}^{-}$ & $4.5^{\mathrm{c}}$ & $0.64^{\mathrm{d}}$ & & & \\
$\mathrm{IO}_{3}^{-}$ & $6.3^{\mathrm{e}}$ & & $0.15^{\mathrm{f}}$ & & \\
$\mathrm{NH}_{3}$ & $4.5^{\mathrm{e}}$ & $2.01^{\mathrm{f}}$ & $3.52^{\mathrm{f}}$ & $4.43^{\mathrm{f}}$ & $5.06^{\mathrm{f}}$ \\
$\mathrm{SO}_{4}^{2-}$ & $2.0^{\mathrm{c}}$ & $1.36^{\mathrm{g}}$ & & & \\
$\mathrm{CO}_{3}^{2-}$ & $5.74^{\mathrm{k}}$ & $3.01^{\mathrm{c}}$ & & & \\
$\mathrm{HCO}_{3}^{-}$ & $3.67^{\mathrm{k}}$ & $0.819^{\mathrm{h}}$ & & & \\
{$\left[\mathrm{H}_{2} \mathrm{PO}_{4}^{-}\right]_{\mathrm{T}}$} & $5.70^{\mathrm{e}}$ & $1.6^{\mathrm{i}}$ & & & \\
{$\left[\mathrm{H}_{2} \mathrm{~S}_{\mathrm{T}}\right.$} & $>99$ & $21.3^{\mathrm{j}}$ & & & \\
\hline
\end{tabular}

All $\beta$ 's are stability constants of a ligand with Co(II), with a standard state solution defined as: $298.15 \mathrm{~K}, 1$ bar, at a seawater ionic strength $(I=0.714)$. $a$, Ahrland (1985); b, calculated from Pan and Susak (1989); c, Byrne et al. (1988); d, Kulvinova et al. (1976); e, Quinby-Hunt and Turekian (1983); $f$, Wagman et al. (1982); g, calculated from Izatt et al. (1969); $h$, calculated in this work; $i$, Hogfeldt (1982); $j$, Smith and Martell (1976); $k$, calculated from Byrne et al. (1988). 


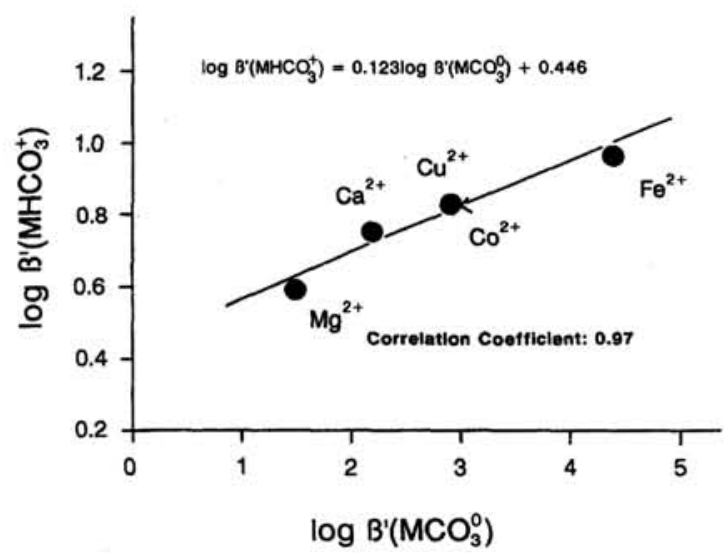

Fig. 2. Linear free energy relationship for bicarbonate, carbonate metal complexes $\left(\mathrm{MHCO}_{3}{ }^{+}\right.$and $\mathrm{MCO}_{3}^{0}$. Sources of data as follows: for $\mathrm{Mg}^{2+}, \log \beta^{\prime}$ $\left(\mathrm{MCO}_{3}^{\circ}\right)$ from Dyrssen and Hanson (1972), $\log \beta^{\prime}$ $\left(\mathrm{MHCO}_{3}^{+}\right)$from Sieber and Hostetler (1977); for $\mathrm{Ca}^{2+}, \log \beta^{\prime}\left(\mathrm{MCO}_{3}^{0}\right)$ from Pytkowicz and Hawley (1974), $\log \beta^{\prime}\left(\mathrm{MHCO}_{3}^{+}\right)$from Cobble et al. (1982); for $\mathrm{Cu}^{2+}, \log \beta^{\prime}\left(\mathrm{MCO}_{3}^{0}\right)$ from Stiff (1971), $\log \beta^{\prime}$ $\left(\mathrm{MHCO}_{3}^{+}\right)$from Cobble et al. (1982); for $\mathrm{Fe}^{2+}, \log \beta^{\prime}$ $\left(\mathrm{MCO}_{3}^{0}\right)$ from Singer and Stumm (1970), $\log \beta^{\prime}$ $\left(\mathrm{MHCO}_{3}^{+}\right.$) from Cobble et al. (1982); for $\mathrm{Co}^{2+}, \log \beta^{\prime}$ $\left(\mathrm{MCO}_{3}^{\circ}\right)$ from Byrne et al. (1988).

calorimetric method which is generally considered more reliable over others.

The concentrations of $\mathrm{F}^{-}, \mathrm{Cl}^{-}, \mathrm{Br}^{-}$and $\mathrm{IO}_{3}^{-}$ are practically $\mathrm{pH}$ independent in natural waters. However, the concentrations of other ligands $\left(\mathrm{CO}_{3}^{2-}, \mathrm{SO}_{4}^{2-}, \mathrm{HCO}_{3}^{-}, \mathrm{H}_{2} \mathrm{PO}_{4}^{-}\right.$, etc. $)$in natural waters are, to various degrees, $\mathrm{pH}$ dependent. At a pH of 8.2, the concentrations of these ligands as free ions are either measured or calculated, as listed in Table 2, for calculating $\mathrm{Co}$ (II) speciation in seawater.

The composition of fresh waters varies according to bedrock lithology, latitude and season (cf. Stumm and Morgan, 1981, Table 8.6). In fresh waters, the $\mathrm{pH}$, the concentrations of ligands (e.g. $\mathrm{CO}_{3}^{2-}, \mathrm{HCO}_{3}^{-}, \mathrm{OH}^{-}, \mathrm{SO}_{4}^{2-}, \mathrm{Cl}^{-}$, and organic ligands) and the ionic electrolyte concentrations may vary over a wide range. Precise calculations are possible only for specific waterbodies. The equations together with the relevant chemical reactions are given in Appendix II, which may be used to calculate the concentra- tions of free ligands in fresh waters when the total ligand concentrations are known. Using these equations, it is possible to calculate $\mathrm{Co}$ (II) speciation schemes in fresh waters as a function of $\mathrm{pH}$.

\section{Results AND Discussion}

\section{(1) In Seawater}

Our calculated $\mathrm{Co}$ (II) speciation scheme in seawater (Table 1) resembles that of Turner et al. (1981), with the major differences in calculated Co(II) carbonate, sulfate and hydroxide complex concentrations. Our calculations show that the principal $\mathrm{Co}$ (II) complexes in seawater are $\mathrm{CoCl}^{+}, \mathrm{CoCl}_{2}^{0}$ and $\mathrm{CoSO}_{4}^{0}$, in decreasing order of abundance. This is in disagreement with Ahrland (1985), Byrne et al. (1988), and to a lesser degree, with Turner et al. (1981). The cobalt speciation scheme is in general agreement with most of the other trace metal speciation schemes in seawater summarized by Millero (1974).

It should be noted that, because the concentrations of $\mathrm{Br}^{-}$and $\mathrm{F}^{-}$in seawater are so low, a change up to two orders of magnitude in the stability constants of the $\mathrm{Co}$ (II) bromide and floride complexes will not noticeably change the calculated $\mathrm{Co}$ (II) speciation scheme (less than $1 \%)$. The same situation is more pronounced for complexes of $\mathrm{Co}(\mathrm{II})$ iodate, hydroxide, phosphate and bisulfide. However, the calculated $\mathrm{Co}$ (II) speciation scheme is sensitive to the stability constants of $\mathrm{Co}$ (II) chloride, sulfate and carbonate complexes, as these ligands exist in seawater at significantly higher concentrations. Byrne et al. (1988) used a stability constant about $0.5 \mathrm{log}$ units less than ours for $\mathrm{CoCl}^{+}$, and consequently underestimated the concentration of $\mathrm{Co}(\mathrm{II})$ chloride in seawater by more than $20 \%$ relative to our model. Our value for the concentration of $\mathrm{Co}$ (II) carbonate complex differs from values estimated by other models, which did not make allowance for the bicarbonate complex.

Byrne et al. (1988) classified all elements in seawater into five groups according to their com- 
plexing nature, with cobalt assessed as a weakly complexed metal. However, our results suggest that cobalt is a transitional weakly-complexed to mainly chloride-complexed metal. Such metals are little influenced by changes in temperature and pH (Byrne et al., 1988). Our calculations show that a pH change from 8.2 to 7.8 causes concentration changes of less than $0.03 \%$ for the most important complexes. Therefore, our calculated cobalt speciation scheme in seawater is generally applicable to most oceanic water masses, regardless of locality or water depth.

Although only small amounts of organic matter (mainly humic acids) are present in seawater (about $340 \mu \mathrm{g} \mathrm{C}$ litre $^{-1}$, Stumm and Morgan, 1981), the presence of organics can cause metal ions to depart from their known inorganic chemistry. However, as pointed out by Stumm and Morgan (1981), the ratio of inorganic to organic constituents is very high in seawater, and $\mathrm{Ca}^{2+}$ and $\mathrm{Mg}^{2+}$ are present at concentrations many orders of magnitude greater than that of trace element ions such as $\mathrm{Co}^{2+}$. Thus, the competition by $\mathrm{Ca}^{2+}$ and $\mathrm{Mg}^{2+}$ organic complexes (removal of organic ligands) and by trace metal inorganic complexes (removal of trace metals) will drastically depress the formation of any trace metal organic complexes. Maljkovic and Branica (1971) found that the degree of $\mathrm{Cd}^{2+}$ complexing with EDTA is diminished by the competition between $\mathrm{Ca}^{2+}$ and $\mathrm{Cd}^{2+}$ for EDTA and by the formation of $\mathrm{CdCl}^{+}$. Huljev's (1986) experiments show that an increase of $\mathrm{NaCl}$ concentration and $\mathrm{pH}$ in aqueous solutions will decrease the fixation of $\mathrm{Ru}, \mathrm{Zn}, \mathrm{Co}$ and $\mathrm{Hg}$ by humic acids. Huljev (1986) pointed out that in the estuarine environment, $\mathrm{Zn}$ and $\mathrm{Co}$ may be rapidly released from humic acids due to the change of $\mathrm{NaCl}$ concentration $(\mathrm{Hg}$ is very slowly released). Turner et al. (1981) suggest that, in seawater at a pH of 8.2 only $\mathrm{Cu}^{2+}$ is significantly complexed by humic acid, with the Co(II) humic acid complex forming about $0.01 \%$ of total Co(II) concentration. Although organic cobalt(II) complexes in seawater can not be ruled out entirely at this stage, it seems that they are less abundant than the free ion and inorganic complexes.

\section{(2) In Fresh waters}

Fresh waters have very low chloride concentrations relative to seawater. Because the total concentration of free anions is much lower in fresh waters, as is the ratio of $\mathrm{Cl}^{-}$to other anions, it is likely that dissolved cobalt in fresh waters exists predominantly as the free ion. Using the relations outlined in the preceding sections and equations in Appendix II, Co(II) speciation schemes in two specific fresh waterbodies were calculated as a function of $\mathrm{pH}$ (Fig. 3). At the specific pH's of the two fresh waters, Co(II) speciations are also listed in Table 3 . The same standard state is retained, but for approximation, no effort were made to correct the effect of ionic strength on the stability constants in fresh waters. According to Fig. 3, in acidic to slightly basic fresh waters, nearly $90 \%$ or more of dissolved $\mathrm{Co}(\mathrm{II})$ is present as the free ion; the remaining $10 \%$ exists as the complexes $\mathrm{CoCO}_{3}^{0}$, $\mathrm{CoSO}_{4}^{0}$ and $\mathrm{CoHCO}_{3}^{+}$. However, the abundance of $\mathrm{CoCO}_{3}^{0}$ increases with $\mathrm{pH}$ and becomes a

Table 3. Ligand concentrations and Co(II) speciations in two fresh waters

\begin{tabular}{lcc}
\hline & \multicolumn{3}{c}{$-\log m$} \\
\cline { 2 - 3 } Ligand & Wind River Formation & \\
& 3.85 & Milk River $^{2}$ \\
\hline $\mathrm{Cl}^{-}$ & - & 3.55 \\
$\mathrm{Br}^{-}$ & 6.27 & - \\
$\mathrm{OH}^{-}$ & 4.83 & 6.35 \\
$\mathrm{~F}^{-}$ & - & 5.05 \\
$\mathrm{IO}_{3}^{-}$ & - & - \\
$\mathrm{NH}_{3}$ & 2.48 & - \\
$\mathrm{TC}$ & 2.85 & 2.14 \\
$\mathrm{TS}$ & 5.92 & 2.48 \\
$\mathrm{TP}$ & & 6.70 \\
\hline $\mathrm{Species}^{2}$ & 93.77 & \\
$\mathrm{Co}^{2+}$ & 1.14 & 87.20 \\
$\mathrm{CoCO}$ & & 2.18 \\
$\mathrm{CoHCO}_{3}^{+}$ & 1.97 & 4.15 \\
$\mathrm{CoSO}_{4}^{0}$ & 3.19 & 6.52 \\
\hline
\end{tabular}

1. Ground water from the Wind River Formation in the Shirley Basin area (Harshman, 1972), averaged values $(p H=7.78)$. 2. Surface water from the Milk River, at the eastern crossing of the Canada/US boundary, Alberta, average $p H=7.65$. Sample was taken at 9:00, January 26, 1982 (Environment Canada, 1985). -, not determined. 

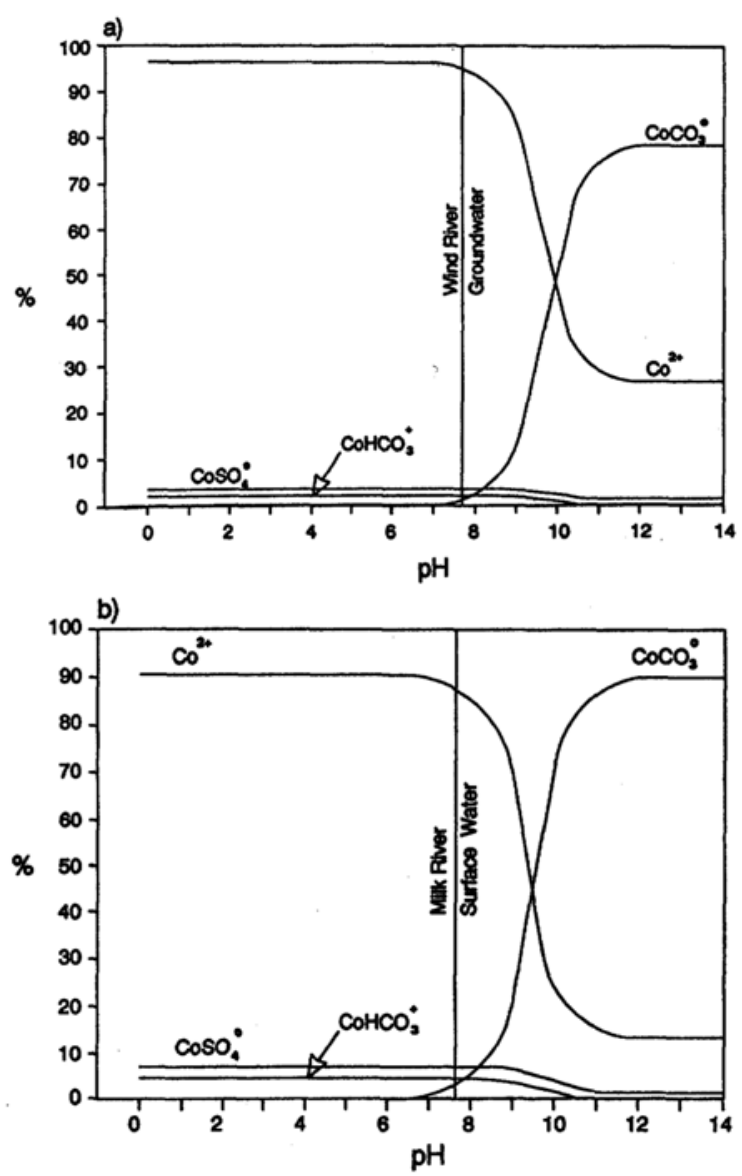

Fig. 3. The speciation of $\mathrm{Co}(\mathrm{II})$ as a function of $p H$. (a) Ground water (average $p H=7.73$ ) from the Wind River Formation in the Shirley Basin area (Harshman, 1972). (b) Surface water (average $p H=7.65$ ) from the Milk River, at the eastern crossing of Canada/US boundary, Alberta. Data to construct these diagrams are listed in Table 3.

significant minor species above a pH of 8.5 and the dominant $\mathrm{Co}^{2+}$ species above a $\mathrm{pH}$ of 9.5 .

In fresh waters, inorganic electrolytes are commonly low in concentration, whereas organic ligands may be relatively concentrated. In such waters, cobalt(II) organic complexes should play a greater role than in seawater, and in some cases may bind a significant amount of cobalt. However, a complete and quantitative assessment of $\mathrm{Co}$ (II) organic complexes in both seawater and fresh waters cannot be accomplished without much further work.

\section{Conclusions}

A simple equilibrium complexing model together with recent experimental data and theoretically estimated data on stabilities of Co(II) chloride, bromide and bicarbonate complexes indicates that about $56 \%$ of the dissolved cobalt in seawater exists as the free ion, $\mathrm{Co}^{2+}$, and another $44 \%$ as complexes of $\mathrm{CoCl}^{+}, \mathrm{CoCl}_{2}^{0}$ and $\mathrm{CoSO}_{4}^{\circ}$ (in decreasing order of abundance). In fresh waters, cobalt exists mainly as the free ion $(90 \%$ or higher), with the cobalt(II) carbonate, sulfate and bicarbonate complexes as the main complexed forms. The organic complexes of $\mathrm{Co}^{2+}$ are most likely less important, relative to the inorganic complexes in seawater; however may at least be locally important in fresh waters. But for both seawater and fresh waters, an appropriate assessment of cobalt organic complexes is not possible at present, more work on this subject is needed.

Acknowledgments-This work was partly supported by the Natural Sciences and Engineering Research Council (NSERC) of Canada and the University of New Brunswick Research Fund. Critical comments by S. A. Wood and T. J. Barrett greatly improved the manuscript. The constructive comments by two referees, Hitoshi Chiba and Robert Symonds are gratefully acknowledged.

\section{REFERENCES}

Ahrland, S. (1985) Inorganic chemistry of the ocean. Environmental inorganic chemistry Irgolic K. J. and Martell A. E. ed., pp. 65-88. VCH, Deerfield Beach.

Brooks, R. R. (1977) Pollution through trace elements. Environmental chemistry Brockris J. M. ed., pp. 429-476. Plenum, New York.

Byrne, R. H., Kump L. R. and Cantrell K. J. (1988) The influence of temperature and $\mathrm{pH}$ on trace metal speciation in seawater. Mar. Chem. 25, 163-181.

Chen, R., Ma, Z. and Zhang, Q. (1984) Linear free energy relationships between stability of complex and basicity of ligands. Acta Chimica Sinica 27, 128-132.

Cobble, J. W., Murray, R. C. Jr., Turner, P. J. and Chen, K. (1982) High-temperature thermodynamic data for species in aqueous solution. EPRI NP-2400 Report. Electric Power Research Institute, Palo 
Alto, California, U.S.A.

Dyrssen, D. and Hansson, I. (1972) Ionic medium effects in sea water-A comparison of acidity constants of carbonic acid and boric acid in sodium chloride and synthetic water. Mar. Chem. 1, 137149.

Elliott, S. (1988) Linear free energy techniques for estimation of metal sulfide complexation constants. Mar. Chem. 24, 203-213.

Environment Canada (1985) Detailed surface water quality data, Alberta, Manitoba, Northwest Territories, and Saskatchewan, 1982.

Goldberg, E. D. (1980) Composition of sea water. McGraw-Hill encyclopedia of ocean and atmospheric sciences (Parker S. P. ed.)

Hancock, R. R., Finkelstein, N. P. and Evers, A. (1977) A linear free-energy relation involving the formation constants of Palladium (II) and platinum (II). J. Inorg. Nuclear Chem. 39, 1031-1034.

Harshman, E. N. (1972) Geology and uranium deposits, Shirley Basin area, Wyoming: U. S. Geol. Survey Prof. Paper 745, 82 pp.

Hogfeldt, E. (1982) Stability constants of metal-ion complexes Part A: Inorganic Ligands. IUPAC, Pergamon Press, Oxford, 310 pp.

Horne, R. A. (1965) The physical chemistry and structure of seawater. Water Resour. Res. 1, 263-276.

Huljev, D. J. (1986) Interaction of some metals between marine-origin humic acids and aqueous solutions. Enviro. Res. 40, 470-478.

Izatt, R. M., Eatough, D., Christensen, J. J. and Bartholomen, C. H. (1969) Calorimetrically determined $\log K, \Delta H_{\mathrm{c}}^{0}$ and $\Delta S^{0}$ values for the interaction of sulphate ion with several bi- and ter-valent metal ions. J. Chem. Soc. (A) 47-53.

Kararet'yants, M. KH and Karapet'yants, M. L. (1970) Thermodynamic constants of inorganic and organic compounds (English translation by $\mathrm{J}$. Schmorak). Ann Arbor, Humphrey Science Publishers.

Kulvinova, L. A., Blokhin, V. V. and Mironov, V. E. (1976) Thermodynamic properties of certain transition metal fluoride complexes in aqueous salt solutions. Russ. J. Phys. Chem. (English Trans.) 50, 773-774 (original pp. 1287-1288).

Maljkovic, D. and Branica, M. (1971) Polarography of sea water, II. Complex formation of cadmium with EDTA. Limnol. Oceanogr. 16, 779-785.

Millero, F. J. (1974) The physical chemistry of seawater. Ann. Rev. Earth \& Plan. Sci. 2, 101-150.

Mountain, B. W. and Wood, S. A. (1988) Chemical control on the solubility, transport, and deposition of platinum and palladium in hydrothermal solutions: A theoretical approach. Econ. Geol. 83, 492510.
Murray, R. C. Jr. and Cubicciotti, D. (1983) Thermodynamics of aqueous sulfur species to $300^{\circ} \mathrm{C}$ and potential-pH diagrams. J. Electro. Chem. Society, 866-869.

Pan, P. (1989) Complexations of Co (II) with chloride and bromide: Spectrophotometric studies and geological implications. Unpub. Ph.D. dissertation, University of New Brunswick.

Pan, P. and Susak, N. J. (1989) Co (II)-chloride and bromide complexes in aqueous solutions up to $5 \mathrm{~m}$ and $90^{\circ} \mathrm{C}$ : Spectrophotometric studies and geological implications. Geochim. Cosmochim. Acta 53, 327-341.

Pearson, R. G. (1963) Hard and soft acids and bases. J. Am. Chem. Soc. 85, 3533-3539.

Pytkowicz, R. M. and Hawley, J. E. (1974) Bicarbonate and carbonate ion-pairs and a model of seawater at $25^{\circ} \mathrm{C}$. Limnol. and Oceanogr. 19, 223224.

Quinby-Hunt, M. S. and Turekian, K. K. (1983) Distribution of elements in sea water. EOS 64, 130132.

Sieber, R. M. and Hostetler, P. B. (1977) The stability of the magnesium bicarbonate ion from $10^{\circ}$ to $90^{\circ} \mathrm{C}$. Am. J. Sci. 277, 697-715.

Singer, P. C. and Stumm, W. (1970) The solubility of ferrous iron in carbonate-bearing water. J. Am. Water Workers Assoc. 62, 198-202.

Smith, A. E. and Martell, R. M. (1976) Critical stability constants $v$. 4. Plenum Press, New York.

Stiff, M. J. (1971) Copper/bicarbonate equilibria in solutions of bicarbonate ion at concentrations similar to those found in natural water. Water Res. 5, 171-176.

Stumm, W. and Brauner, P. A. (1975) Chemical speciation. Chemical oceanography, 2nd ed., Vol. 1 Riley J. P. and Skirrow G. eds, pp. 173-239. New York, Academic.

Stumm, W. and Morgan, J. J. (1981) Aquatic chemistry. 2nd ed., Wiley-Interscience, New York, $736 \mathrm{pp}$.

Turner, D. R., Whitfield, M. and Dickson, A. G. (1981) The equilibrium speciation of dissolved components in fresh water and seawater at $25^{\circ} \mathrm{C}$ and 1 atm pressure. Geochim. Cosmochim. Acta 45, 855881.

Van Panthelon Van Eck, C. K. (1953) On the internal stability relationship of $\mathrm{MeA}_{\mathrm{n}}$, complexes consisting of a metal ion $\mathrm{Me}$ and a ligand $\mathrm{A}$ in aqueous solution, for consecutive values of n. Rec. Trav. Chim. Pays-Bas 72, 529-537.

Wagman, D. D., Evans, W. H., Parker, V. B., Schumm, R. H., Halow, I., Bailey, S. M. Churney, K. L. and Nuttall, R. C. (1982) The NBS tables of chemical thermodynamic properties, selected values 
for inorganic and $\mathrm{C}$ organic substances in SI units. J. Phys. Chem. Ref. Data 11, Supplement 2.

\section{Appendix I}

From the Van Pantheleon Van Eck equation (Van Pantheleon Van Eck, 1953),

$$
\log K_{n}=\log K_{1}-2 \lambda(n-1)
$$

Where, $K_{1}$ and $K_{n}$ are the stepwise formation constants for the first and nth complex respectively, of a metal $M$ with a ligand $L, \lambda$ is an empirical constant for each specific system, and $n$ is the ligation number. Because

$$
\log \beta_{n}=\sum_{i=1}^{N} \log K_{i}
$$

we can show that:

$$
\log \beta_{n}=n\left[\log \beta_{1}+(1-n) \lambda\right]
$$

or:

$$
\log \frac{\beta_{n}}{\beta_{1}^{n}}=n(1-n) \lambda
$$

We know by definition that $n \geq 1$. For most known aqueous systems (Van Pantheleon Van Eck, 1953; Pan, 1989), $\lambda>0$, then

$$
\log \frac{\beta_{n}}{\beta_{1}^{n}} \leq 0
$$

or

$$
\beta_{n} \leq \beta_{1}^{n}
$$

by definition

$$
\beta_{n}=\frac{\left[M L_{n}\right]}{[M][L]^{j}}
$$

then

$$
\frac{\left[M L_{n}\right]}{[M][L]^{n}} \leq \frac{[M L]}{[M][L]}
$$

or

$$
\frac{\left[M L_{n}\right]}{[M L]} \leq[L]^{n-1}
$$

Therefore, for diluted solutions, $[L]<1 \mathrm{~m}$, $\left[M L_{n}\right]<[M L]$. 


\section{APpendix II Equations for free ligand} concentration calculations

$$
\begin{aligned}
& \mathrm{H}_{2} \mathrm{O}=\mathrm{H}^{+}+\mathrm{OH}^{-} \\
& \mathrm{K}_{\mathrm{w}}=10^{-14} \\
& {\left[\mathrm{OH}^{-}\right]=\mathrm{K}_{\mathrm{w}} /\left[\mathrm{H}^{+}\right]} \\
& \mathrm{CO}_{3}^{2-}+\mathrm{H}^{+}=\mathrm{HCO}_{3}^{-} \\
& \mathrm{HCO}_{3}^{-}+\mathrm{H}^{+}=\mathrm{H}_{2} \mathrm{CO}_{3}^{0} \\
& \mathrm{~K}_{\mathrm{Cl}}=1.78 \times 10^{10} \\
& \mathrm{~K}_{\mathrm{C} 2}=2.73 \times 10^{6} \\
& {\left[\mathrm{CO}_{3}^{2-}\right]=\mathrm{TC} /\left(1+\mathrm{K}_{\mathrm{C} 1}\left[\mathrm{H}^{+}\right]+\mathrm{K}_{\mathrm{C} 1} \mathrm{~K}_{\mathrm{C} 2}\left[\mathrm{H}^{+}\right]^{2}\right)} \\
& {\left[\mathrm{HCO}_{3}^{-}\right]=\mathrm{K}_{\mathrm{Cl}}\left[\mathrm{H}^{+}\right]\left[\mathrm{CO}_{3}^{2-}\right]} \\
& \mathrm{PO}_{4}^{3-}+\mathrm{H}^{+}=\mathrm{HPO}_{4}^{2-} \\
& \mathrm{HPO}_{4}^{2-}+\mathrm{H}^{+}=\mathrm{H}_{2} \mathrm{PO}_{4}^{-} \\
& \mathrm{H}_{2} \mathrm{PO}_{4}^{-}+\mathrm{H}^{+}=\mathrm{H}_{3} \mathrm{PO}_{4}^{0} \\
& \mathrm{~K}_{\mathrm{P} 1}=4.5 \times 10^{12} \\
& \mathrm{~K}_{\mathrm{P} 2}=1.61 \times 10^{7} \\
& \mathrm{~K}_{\mathrm{P} 3}=133 \\
& {\left[\mathrm{PO}_{4}^{3-}\right]=\mathrm{TP} /\left(1+\mathrm{K}_{\mathrm{P} 1}\left[\mathrm{H}^{+}\right]+\mathrm{K}_{\mathrm{P} 1} \mathrm{~K}_{\mathrm{P} 2}\left[\mathrm{H}^{+}\right]^{2}+\mathrm{K}_{\mathrm{P} 1} \mathrm{~K}_{\mathrm{P} 2} \mathrm{~K}_{\mathrm{P} 3}\left[\mathrm{H}^{+}\right]^{3}\right)} \\
& {\left[\mathrm{H}_{2} \mathrm{PO}_{4}^{-}=\mathrm{K}_{\mathrm{P} 1} \mathrm{~K}_{\mathrm{P} 2}\left[\mathrm{H}^{+}\right]^{2}\left[\mathrm{PO}_{4}^{3-}\right]\right.} \\
& \mathrm{SO}_{4}^{2-}+2 \mathrm{H}^{+}=\mathrm{H}_{2} \mathrm{~S}+2 \mathrm{O}_{2} \\
& \mathrm{~K}_{\mathrm{S} 1}=10^{-132} \\
& \mathrm{H}_{2} \mathrm{~S}=\mathrm{H}^{+}+\mathrm{HS}^{-} \\
& \mathrm{K}_{\mathrm{S} 2}=1.02 \times 10^{-7} \\
& {\left[\mathrm{HS}^{-}\right]=\mathrm{TS} /\left(1+\left[\mathrm{H}^{+}\right] / \mathrm{K}_{\mathrm{S} 2}+\mathrm{f}_{\mathrm{O} 2} /\left(\mathrm{K}_{\mathrm{S} 1} \mathrm{~K}_{\mathrm{S} 2}\left[\mathrm{H}^{+}\right]\right)\right)} \\
& {\left[\mathrm{H}_{2} \mathrm{~S}\right]=\left[\mathrm{H}^{+}\right]\left[\mathrm{HS}^{-}\right] / \mathrm{K}} \\
& {\left[\mathrm{SO}_{4}^{2-}\right]=\left[\mathrm{H}_{2} \mathrm{~S}\right] \mathrm{f}_{\mathrm{O} 2} /\left(\mathrm{K}_{\mathrm{Sl}}\left[\mathrm{H}^{+}\right]^{2}\right)}
\end{aligned}
$$

TC, total carbon; TP, total phosphorus; TS, total sulfur. All equilibrium constants except $\mathrm{K}_{\mathrm{S} 1}$ and $\mathrm{K}_{\mathrm{S} 2}$ are from "CRC Handbook of Chemistry and Physics", 63 Ed. (1982-1983). $\mathrm{K}_{\mathrm{S} 1}$ and $\mathrm{K}_{\mathrm{S} 2}$ were calculated using data in Murray and Cubicciotti (1983). 